\title{
EXPLORING CONSUMER PREFERENCES AND FACTORS ASSOCIATED WITH VEGETABLE CONSUMPTION
}

\author{
Dragana N. Ubiparip Samek ${ }^{* 1}$, Aleksandra R. Bajić ${ }^{1}$, Lato L. Pezo ${ }^{2}$, Renata M. Kovač ${ }^{1}$, Jasna S. Mastilović ${ }^{1}$, \\ Tihomir S. Zoranović ${ }^{3}$, Branislav I. Vlahović ${ }^{3}$ \\ ${ }^{1}$ University of Novi Sad, Institute of Food Technology, 21000 Novi Sad, Bulevar cara Lazara 1, Serbia \\ ${ }^{2}$ University of Belgrade, Institute of General and Physical Chemistry, 11000 Belgrade, Studentski trg 12/V, \\ Serbia \\ ${ }^{3}$ University of Novi Sad, Faculty of Agriculture, Department of Agricultural Economics, 21000 Novi Sad, Trg \\ D. Obradovića 8, Serbia
}

\begin{abstract}
The consumers' preferences and their reasons for vegetable consumption were examined with the aim to provide useful information to increase the consumption of these food items. Consumers' general viewpoints about vegetable consumption were examined using an online questionnaire. The study was conducted on a sample of 711 respondents chosen randomly and obtained data were analyzed by the correspondence analysis. Results suggest that consumers consider vegetables as tasty, easy to use and healthy for consumption. The main drawbacks for vegetable consumption are safety issues, short shelf-life and high price. In order to increase the consumption of these foodstuffs, each type of fresh and processed vegetable should have a specifically designed campaign, emphasizing its specific attribute. Obtained results might provide an insight into the current state of consumers' behavior in Serbia and might be useful for creating specific promotional programs and more appropriate communication strategies aiming to increase consumers' knowledge about the importance of regular vegetable consumption. They should raise consumers' awareness by emphasizing the importance of adequate daily vegetable consumption. This, in turn, should improve public health and reduce the health and economic costs of massive chronic diseases caused by inadequate diet.
\end{abstract}

Key words: consumer behavior, fresh vegetables, processed vegetables, correspondence analysis

\section{INTRODUCTION}

The relationship between fruit and vegetable consumption and different chronic diseases has been a popular topic among researchers (Boeing et al., 2012; Nguyen et al., 2016), since their regular consumption represents an important element of a healthy and balanced diet (Menozzi, Sogari \& Mora, 2015). Current data indicate that many consumers do not consume adequate amounts of fruit and vegetables (Menozzi et al., 2015), due to the influence of a wide range of sociodemographic factors, such as gender, age and ethnicity (Blanchard et al., 2009; Emanuel, McCully, Gallagher \& Cherry, 2012), as well 
as the income and cost (Chapman et al., 2017; Allen et al., 2017).

In Serbia, there is a shortage of scientific research dealing with fruit and vegetable consumption. Previously published data reported insufficient consumption of these groceries, in spite of their nutritionally valuable composition and importance on human health (Rodić-Trmčić, Ivanović \& Ilić, 2015). Daily fruit and, particularly, vegetable intake among residents of Serbia were at a low level and only $45.6 \%$ of Serbian residents consume fruits and $57.1 \%$ consume vegetables every day (Institute of Public Health of Serbia, 2019). The consumption is even lower in the north, since $40.4 \%$ and $44 \%$ of residents eat fruits and vegetables, respectively, on a daily basis. Consumers with a higher level of education and higher income tend to consume more fruits and vegetables (Institute of Public Health of Serbia, 2019).

Therefore, the study aims to examine consumers' general attitudes and viewpoints about vegetable consumption in north Serbia, including the most popular vegetable types, as well as the reasons for the consumption of different forms of vegetables. Obtained results might help in creating prospective promotional programs and strategies aimed to increase vegetable consumption. The authors consider this issue as highly significant for a better understanding of the current state of public health. The study pinpoints the problems of vegetable usage and points out the methods for rising consumers' awareness about this type of food, in order to improve people's health and their lifestyle, in general.

\section{MATERIALS AND METHODS}

The present study is a part of a larger research about fruit and vegetable consumption in north Serbia conducted between September 2016 and May 2017. Beside the socio-demographic part of the questionnaire, the following questions are used:

Q1: the most important reasons for consumption of different types of vegetables (tomato, potato, paprika, cabbage, cucumber, lettuce, onion, garlic and greens),

Q2: the most important reasons for consumption of different forms of vegetables (fresh, frozen, canned or vegetable juice).

\section{Subject}

The survey was conducted among 711 randomly selected consumers in the northern part of Serbia using a self-administrated online questionnaire (Survey Monkey, Inc.) Consumers were recruited via social networks and emails. The sample consisted of $66 \%$ females and $34 \%$ males. Women were more willing to participate in the study as they are usually the food providers for the family as well as decision makers (Arce, Gugole, Ottaviano \& Sosa, 2021). Middle-aged respondents (age 25 to 45) had the largest proportion (43.62\%), older respondents (age above 45) had a lower share $(20.48 \%)$ and young respondents (age below 25) had the smallest share $(5.59 \%)$. Participation of respondents with and without a college degree, as well as the married and single respondents, was approximately at the same level. The largest number of participants had four family members $(36.97 \%)$. As for income, the largest share $(26.50 \%)$ had income between 25,000 and 49,999 RSD (approximately between $250 €$ and $500 €$ ) representing the average income in Serbia. The sample represents the population of north Serbia in an adequate manner.

\section{Methodology \\ Preliminary study}

In this preliminary study 20 participants were surveyed using the free listing technique as a simple and powerful consumer research method to gain insight into specific food category (Hough \& Ferrais, 2010; Arce et al., 2021). Firstly, participants had to write a list of vegetable types and forms they like and often eat. After that, they were asked to indicate the reasons they find important for vegetable consumption, both positive and negative. The reasons with similar meanings were grouped into different categories (Arce et al., 2021; Viana et al., 2021): composition (healthy and safe), preferences (tasty, high-quality food and family members love it), supply (domestic, seasonal, long shelf-life) and convenience (easy to use, often used for meal preparation, good for salad, good snack). Terms mentioned by more than $10 \%$ of the respondents were included in the questionnaire (Hough \& Ferrais, 2010; Arce et al., 2021). The most mentioned vegetables (tomato, potato, paprika, cabbage, cucumber, lettuce, onion, garlic and greens) and the most mention reasons were used for Q1. The most mentioned forms (fresh, 
frozen, canned and juice) and the same groups of reasons were used for Q2.

\section{Statistical Analysis}

Correspondence analysis with a symmetric normalization model (Lebart, 1984; Hoffman \& Franke, 1986; Beh, 2004) was performed in the frequency table that contains the key reasons for vegetable type and forms consumption. All statistical analyses were performed using Statistica 12.0 software (StatSoft, Tulsa, OK, USA). All variables and objects were plotted on a perceptual map that visually presents numerical tabular data in a simple graphical presentation (Greenacre, 2017) showing the overall data relationship (Ivy, 2001).

\section{RESULTS AND DISCUSSION}

\section{Results and discussion}

\section{Reasons for consumption of different vegetable types}

Perceptual map of the most important reasons for consumption of the mentioned vegetable types (Q1) is presented in Figure 1. Substantial differentiation among reasons for consumption of different kinds of vegetables was detected. Significant correspondence was detected among the considered categories (total inertia was $0.156 ; \chi^{2}$ was $\left.2973.7 ; \mathrm{p}<0.001\right)$. The first two dimensions account for $91.5 \%$ of the total inertia using a considerably satisfactory quota of the raw information.

According to the positions in the perceptual map, several conclusions can be made. Garlic, onion, greens and potato are positioned on the right, while cabbage, tomato, paprika, cucumber and lettuce are positioned on the left side of the perceptual map which is differentiated by dimension 1 which accounts for $61.1 \%$ of total inertia. It can be seen that the key reasons for the consumption of garlic, onion and greens are their "utilization for meal preparation" and "long shelf-life". The reasons associated with consumption of the left positioned vegetables, in particular lettuce, are their utilization for the salad or snack. The characteristics as "quality", "healthy", "my family loves it" and "easy to use" are, in respect to horizontal dispersion of the reasons, positioned close to the central part, meaning that consumers attribute them to all vegetable types. The characteristics "tasty" and "domestic" are placed close to the origin, indicating a limited distinction from each other, as well as their attribution to all types of vegetables. Vegetables from the second group in respect to dimension 1 (cabbage, tomato, paprika, cucumber and lettuce) are all positioned close to the central line in respect to dimension 2 which accounts for $30.4 \%$ of total inertia. These vegetables are all considered to be "tasty", "good for the salad" and "with seasonal character". Oppositely, in the first group in respect to dimension 1 (garlic, onion, greens and potato), there is a clear differentiation of two groups in respect to dimension 2. They can be associated to several reasons which are similarly positioned: they are "used for meal preparation", they are considered to be "safe", of adequate "quality" and "healthy". The potato which is positioned in the lower right part of the perceptual map can be associated with the fact that it is "cheap" and "easy to use". To analyze emphasized observations the frequencies of the reasons for consumption of the specific type of vegetables are summarized and listed in a contingency table of frequencies obtained by aggregating answers over respondents, after applying the correspondence analysis (Table 1).

Reasons for consumption of vegetables were categorized into 4 major groups:

1. The reasons related to vegetable composition including the healthy nutritious components on one, and its safety from the aspect of the content of health-endangering substances on the other side;

2. The reasons related to consumers' preferences including the taste, quality, the fact that the family members like it and price;

3. The reasons related to the supply aspects of vegetable availability to the consumers, including the fact that it is domestic i.e. produced locally, its seasonal character and its shelf-life, and

4. The reasons related to the convenience of vegetables for utilization, including the ease of utilization and its convenience to be used in different forms in daily meals: for meal preparation, as a salad and as a snack. 


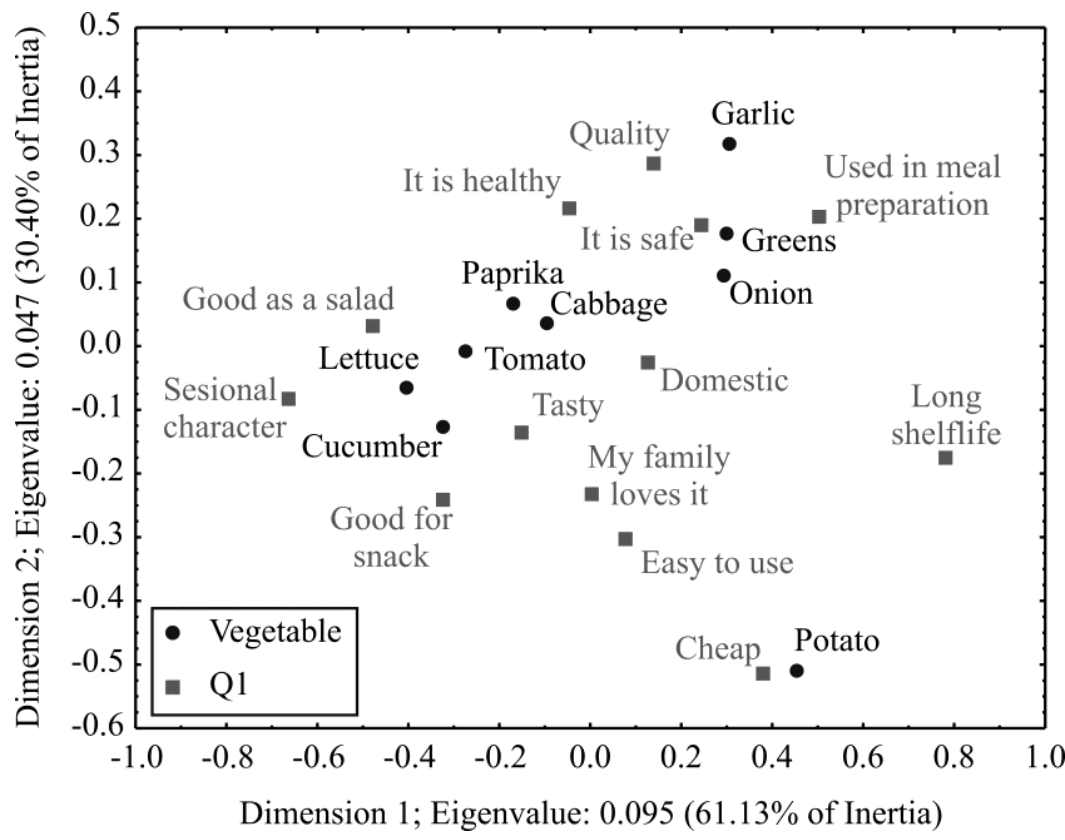

Figure 1. Correspondence between the selected types of vegetables and the consumption reasons

Table 1.

Reasons for specific vegetable types consumption (\% of respondents)

\section{Vegetables}

Reasons for consumption

\begin{tabular}{|c|c|c|c|c|c|c|c|c|}
\hline $\begin{array}{l}\stackrel{0}{\overparen{E}} \\
\stackrel{\Xi}{0} \\
\stackrel{E}{E}\end{array}$ & $\begin{array}{l}\stackrel{0}{\pi} \\
\stackrel{0}{0} \\
0\end{array}$ & 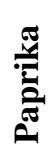 & 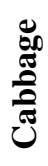 & 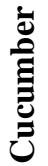 & لِّلِ & 苂 & 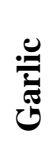 & 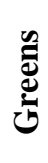 \\
\hline
\end{tabular}

\section{COMPOSITION}

\begin{tabular}{lccccccccc} 
Healthy & 24.8 & 9.9 & 25.7 & 26.3 & 22.7 & 25.4 & 26.7 & 31.2 & 27.4 \\
Safe & 0.8 & 1.1 & 1.2 & 1.2 & 1.1 & 0.8 & 1.6 & 2.1 & 1.8 \\
\hline PREFERENCES & & & & & & & & & \\
Tasty & 21.6 & 17.9 & 19.1 & 15.1 & 19.4 & 17.4 & 10.9 & 10.3 & 12.7 \\
Quality & 3.4 & 2.3 & 4.1 & 4.0 & 3.1 & 3.0 & 4.4 & 7.2 & 5.4 \\
Cheap & 1.9 & 13.0 & 1.6 & 5.5 & 4.5 & 4.2 & 6.6 & 2.2 & 4.6 \\
Family loves it & 9.4 & 13.0 & 8.4 & 7.4 & 7.9 & 8.5 & 6.0 & 6.3 & 5.9 \\
\hline SUPPLY & & & & & & & & & \\
Domestic & 6.4 & 8.4 & 6.6 & 6.0 & 6.6 & 5.1 & 7.9 & 7.2 & 7.7 \\
Seasonal & 3.9 & 0.6 & 3.9 & 1.8 & 4.2 & 5.3 & 0.5 & 0.6 & 1.4 \\
Long shelf-life & 0.3 & 6.6 & 0.8 & 2.2 & 0.9 & 0.4 & 4.4 & 4.8 & 3.0 \\
\hline CONVINIENCE & & & & & & & & & \\
Easy to use & 5.4 & 10.8 & 5.5 & 4.4 & 7.1 & 6.1 & 5.1 & 4.0 & 5.6 \\
Use it in meals & 6.4 & 13.1 & 9.2 & 8.7 & 2.9 & 2.6 & 17.0 & 17.5 & 18.8 \\
Good for a salad & 14.2 & 1.8 & 12.5 & 16.4 & 17.1 & 19.5 & 8.7 & 6.1 & 4.7 \\
Good for a snack & 1.6 & 1.4 & 1.4 & 1.1 & 2.4 & 1.7 & 0.4 & 0.5 & 1.0 \\
\hline
\end{tabular}




\section{Reasons related to the vegetable composition}

There are two main outcomes of this study regarding vegetable composition, one related to consumers' awareness of health benefits from vegetable consumption and the other related to the confidence in vegetable safety aspects.

Knowledge related to the health benefits from vegetable consumption is permanently upgraded through numerous research activities emphasizing the presence of nutritionally valuable compounds that are highly nutritious and have a significant beneficial impact on human health (WHO 2003). According to the results, the major reason for the use of all the vegetables (22.7-31.2\%), except for the potato $(9.9 \%)$, is based on a belief that those vegetables are healthy. Although it represents one of the staple foods in Serbian cuisine, the potato was underestimated as a healthy foodstuff in this work, probably due to the lack of consumers' knowledge about its nutrition profile. The survey conducted by Wood, Charragher \& Davis (2017) showed that potato is a nutritionnally valuable crop. This finding confirms that carefully planned promotion of health-boosting properties of vegetable might be a powerful tool for an increase of its consumption in consumers.

Vegetable safety is an issue of concerns for many consumers nowadays. One of the systematic investigations of pesticide content showed that in over $50 \%$ of tomato samples (81), residue level exceeded the maximum level in the case of at least one pesticide (Pucarević, 2008). The worrying levels of pesticide in vegetables and the fact that they are usually consumed fresh (in salads or as snacks) consumers' concern about their safety was at a high level in this research. Accordingly, none of the investigated vegetables was believed to be safe for consumption as shown in Table 1 (0.8-1.8\%). The development of constant pesticide monitoring and transparent presentation of the obtained results are the prerequisites for overcoming the safety issues. The other approach for overcoming safety issues might be the transfer of information to the consumers for pesticide removal, for example, washing the vegetables with tap water or adequate chemical solutions (detergent, etc.) at home (Aguilera, Valverde, Camacho, Boulaid, Gar-
cia-Fuentes, 2014), juicing and peeling as the pesticide residues are commonly distributed to the surface (Abou Arab, 1999) or adequate storage that might lead to residue reduction (Cengiz, Certel \& Göçmen, 2006).

\section{Reason related to consumers' preferences}

Consumer personal preferences depend on a number of factors. In the case of vegetable, among those factors are sensory properties including taste (Ion, 2015), quality (Coulibaly, Nouhoheflin, Aitchedji, Cherry \& Adegbola, 2011), inputs from persons whose opinion is relevant for the consumers (Brown, 2003), as well as economic factors like price (Guerrero, Abad, García \& Jiménez, 2012) or income (Arce et al. 2021).

Among the reasons related to consumers preferences based on our study, taste appeared to be the most important reason for vegetable consumption. The results recognized cucumber, cabbage, lettuce, tomato, paprika as tasty $(19.4 \%, 15.1 \%, 17.4 \%, 21.6 \%$ and $19.1 \%$, respectively) with taste being the second most important reason for consumption right after benefits for health. For greens, onion and garlic, the taste was also among the three most important reasons $(10.9 \%, 10.3 \%$ and $12.7 \%$ respectively), while in the case of potato it was the most important reason for consumption $(17.9 \%)$. Since the taste preferences are formed in childhood (Zeinstra, Koelen, Kok \& De Graaf, 2007), the development of taste towards a wider pallet of vegetables among children might become an efficient strategy for increase of - vegetable consumption in the future generations.

Oppositely to the taste, the quality of vegetable was detected as the reason for vegetable consumption in $3 \%$ to $7.2 \%$ cases and was not recognized as major reasons for vegetable consumption. For the consumer, the quality of vegetable is determined by various properties like fruit size, uniformity of size, color, bruises and other damages, skin integrity, freshness, firmness etc. (Coulibaly et al., 2011). In Serbia, the classification, postharvest preservation of quality in the supply chain and presentation of vegetable at the selling points is on a lower level in comparison to developed countries. Therefore, improvement of quality preservation and presentation techniques might be among the successful strategies for vegetable consumption increase. 
Considering the price, potato is the only vegetable from the offered list that is consumed due to its low price $(13.0 \%)$. The increasing trend of vegetable prices on Serbian market (Mihajlović, Vukelić, Novković, \& Mutavdžić, 2019) resulted in a decrease in vegetable consumption. However, this observation might lead to future improvements in vegetable classification and/or offering of second class goods at lower and more affordable prices thus might increase vegetable consumption in consumers with lower income level.

The fact that family loves some type of vegetable is among the top reasons for vegetable consumption for slightly higher proportion of consumers (5.9\%-13.0\%). Comprehensive action might change the habits of the whole families. However, this feature is not among the top-rated, thus this approach might not be crucial for vegetable consumption improvement.

\section{Reason related to vegetable supply}

Among the factors related to vegetable supply the importance of domestic origin, seasonal supply and shelf-life were included in investigations.

The highest number of respondents identified domestic origin $(5.1-8.4 \%)$ as one of the three top reasons for the consumption of specific types of vegetables. However, this score is lower in comparison to the main factors identified (health benefits and taste). Nevertheless, promotion of vegetable with domestic origin might be contributed to successful campaigns for incensement in vegetable consumption.

Seasonal character is not recognized as the reason which improved vegetable consumption $(0.5-3.9 \%)$. This is a consequence of the continual availability of almost all vegetable types on the Serbian market during the whole year. The seasonal character of vegetable is not an issue anymore due to the presence of contemporary supply chains. In combination with lower price, domestic products might be promoted as the ones for which seasonal consumption might be increased.

A long shelf-life is not perceived by the consumers among the key reason for vegetable consumption (0.3-3.0\%). Such opinion can be contributed to the short shelf-life of most vegetables. On the other hand, modern cultivars and postharvest technologies succeeded in the extension of shelf-life for many fresh com- modities including most of the vegetables in this research. However, inadequate conditions in vegetable supply chains in Serbia, as well as an absence of education among consumers can be listed as the reasons for consumers' opinion about this reason for vegetable consumption.

Still, some of the mentioned shortcomings may be surpassed. A short shelf-life and seasonal character could be overcome by the implementation of good agricultural practices and application of various postharvest technologies and treatments. In domestic conditions, the consumers usually have two main options for storing the perishable fresh produce: room or refrigerator. It should be noted that refrigerating conditions often have harmful effect on the sensory preferable aroma and flavor, thus affects its sensory quality (Renard, Ginies, Gouble, Bureau \& Causse, 2013) and overall acceptance.

\section{Reason related to vegetable convenience for utilization}

Consumers in north Serbia, in general, do perceive vegetables as easy to use (only 4.4$10.8 \%$ answers were obtained) and, in general, do not have difficulties in their preparation for consumption.

Consumers recognize cucumber, cabbage, lettuce, tomato and paprika as good for salad preparation $(17.1 \%, 16.4 \%, 19.5 \%, 14.2 \%$ and $12.5 \%$, respectively). The present study also showed that greens, garlic, onion and potato are recognized as vegetables used in meal preparation $(18.8 \%, 17.5 \%, 17.0 \%$ and $13.0 \%$ respectively). The promotion of new, inventive ways for utilization of vegetables, both in processed dishes and in salad might contribute to the increase of vegetable consumption.

An interesting point is that the vegetable is not recognized as convenient to be used as a snack (only $0.4-1.7 \%$ of correspondents state that opinion). Using vegetable as a snack and production of vegetable-based snack should be also considered as an opportunity for actions directed towards an increase in vegetable consumption (Baselice, Colantuoni, Lass, Nardone \& Stasi, 2017), particularly among consumers having snacks out of their homes (students and school children) (Baselice et al., 2017).

\section{Specific vegetable consumption forms}

The second part of the research aimed to detect the most important reasons for fresh and 
processed (frozen, canned or juice) vegetable consumption. The main reasons, based on the correspondence analysis, are presented in Figure 2. The first two dimensions account for $98.0 \%$ of the total inertia (total inertia was 0.334; $\chi^{2}$ was 2627.1; $p<0.001$ level).

From the position of vegetable forms and reasons for their consumption in the perceptual map clear differentiation, based on dimension 1 (accounting for $80.4 \%$ of inertia) can be noted. Canned and frozen vegetables positioned on the right side are associated with "long shelf-life", "easy to use", "used in meal preparation" and "low price". Fresh vegetables

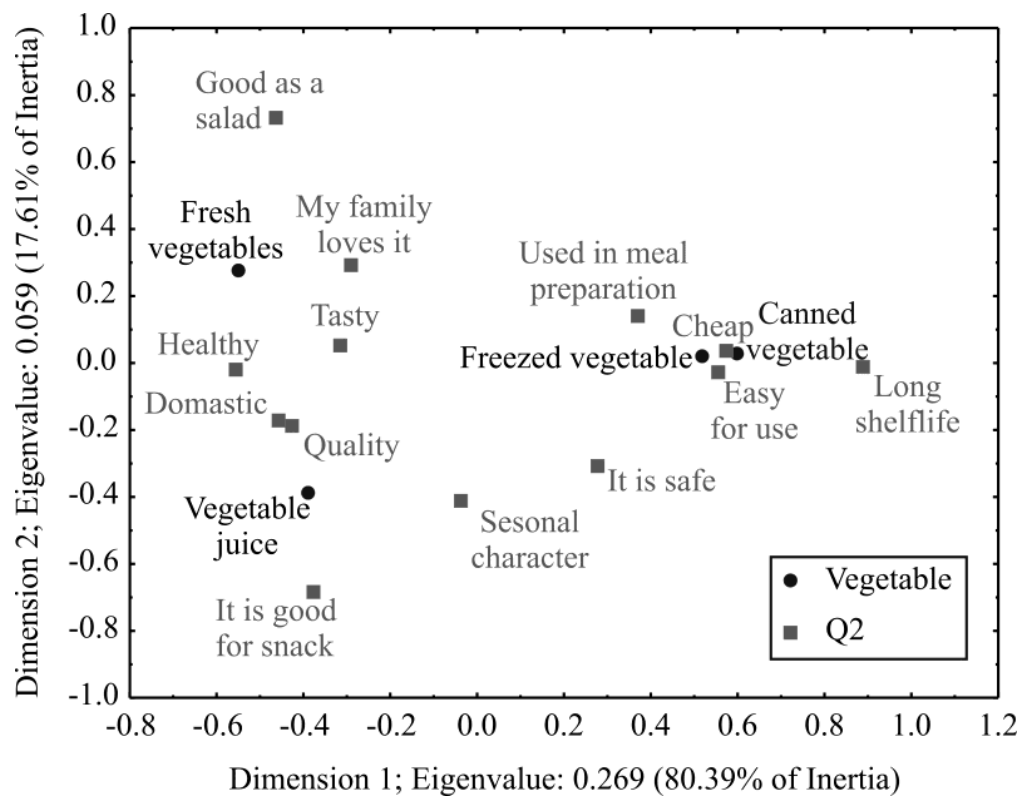

Figure 2. Correspondence between the reasons for consumption of different forms of vegetables

Table 2.

Reasons for specific forms of vegetables consumption (\% of respondents)

\begin{tabular}{lcccc}
\hline \multirow{2}{*}{ Reason for consumption } & \multicolumn{4}{c}{ Form of vegetables } \\
\cline { 2 - 6 } COMPOSITION & Fresh & Frozen & Canned & Juice \\
Healthy & 31.1 & 9.6 & 6.3 & 28.6 \\
Safe & 1.0 & 3.2 & 3.8 & 3.6 \\
\hline PREFERENCES & & & & \\
Tasty & 19.0 & 9.1 & 8.9 & 15.5 \\
Quality & 7.7 & 3.4 & 3.0 & 9.9 \\
Family loves it & 7.4 & 3.8 & 2.6 & 3.4 \\
\hline SUPPLY & & & & \\
Domestic & 3.8 & 1.3 & 1.5 & 4.7 \\
Seasonal & 1.6 & 3.6 & 1.5 & 4.7 \\
Cheap & 1.6 & 5.7 & 6.0 & 1.8 \\
Long shelf-life & 0.5 & 19.9 & 22.8 & 3.7 \\
\hline CONVENIENCE & & & & \\
Easy to use & 5.4 & 20.8 & 23.7 & 8.6 \\
Good for a snack & 2.5 & 1.3 & 2.8 & 9.4 \\
Use it in meals & 8.2 & 16.6 & 13.4 & 5.2 \\
Good for a salad & 10.2 & 1.6 & 3.5 & 0.9 \\
\hline
\end{tabular}


and vegetable juices positioned on the left side are associated with the "health benefits", "good taste", "quality", "good for a snack", "good for a salad" and "loved by the whole family".

Canned and frozen vegetables are positioned close to the central line in respect to dimension 2 which accounts for $17.6 \%$ of total inertia meaning that consumers do not particularly differentiate between these two forms of vegetable. Oppositely, in respect to dimension 2 , there is a clear differentiation between fresh vegetable and vegetable juices, the first being consumed as a salad and the second as a snack.

The frequencies of emphasizing certain reasons for consuming vegetables in their fresh or specific processed form (Q2) by the consumers are summarized according to the offered answers and listed in the contingency table of frequencies obtained by aggregating answers over respondents, after applying the correspondence analysis (Table. 2).

The results claim that fresh vegetables are considered as "healthy" (31.1\%), "tasty" (19.0\%) and "good for a salad" (10.2\%). Frozen and canned vegetables are labelled as "easy to use" (20.8\% and $23.7 \%$, respectively), "longlasting" (19.9\% and $22.8 \%$, respectively) and "used for meal preparation" (16.6\% and $13.4 \%$, respectively). Freezing and canning are commonly used methods for preserving the nutritional value of various commodities (Rickman, Barrett \& Bruhn, 2007) and could help in overcoming the time-limited consumption of seasonal vegetables during the year. Commonly used heat pre-treatment in vegetable preserving is short term blanching (Cengiz et al., 2006). The technology of vegetable preserving is mostly focused on heat treatments (blanching, pasteurization, sterilization, etc.), freezing techniques, utilization of fermentation methods such as pickling, and others. Seasonal vegetables like paprika, cabbage, and cucumbers are traditionally fermented and commonly consumed during the winter-time as pickled vegetables in Serbia, thus have a prolonged shelf-life. Canned vegetables were considered the least healthy form of all processed vegetables (6.3\%). But, they could supply consumers' needs for all nutrients since they have a similar concentration of those compounds as a fresh counterpart, in spite of the loss of some vitamins during initial thermal processing (Featherstone, 2016). According to
Rickman et al., (2007) some nutrients are more stable in canned products due to a lack of oxygen during the storage period. Still, canning is commonly negatively observed because of the use of chemical preservatives, which could be the reason for the correspondents' perception and finally positioning of canned vegetables at a lower level in terms of health properties. Also, the frozen vegetables were characterized as less healthy $(9.6 \%)$ than fresh. Li, Pegg, Eitenmiller, Chun \& Kerrihard (2017) pointed out that fresh vegetables and fruits do not have significantly higher nutritional value in comparison to the same frozen products. Those authors reported that most of the examined frozen products were superior over the freshly stored produce. Informing the consumers about these details might be a strategy for an increase of vegetable intake through increased consumption of processed vegetable which is cheaper and easier to use.

The taste of frozen and canned commodities was emphasized among the reasons for consumption by a lower proportion of consumers (9.1\% and $8.9 \%$, respectively) in comparison to the fresh produce $(19.0 \%)$. The use of freezing or canning as a food preservation technique could induce less or more severe damage in vegetables which could be reflected in texture loss, flavor modification, change in taste and color, causing a negative shift in overall sensory perception of the product (Rickman et al., 2007; Jha, Xanthakis, Chevallier, Jury \& Le-Bail, 2019). Improvement of freezing techniques or promotion of innovative ways for utilization of frozen vegetables might be used as the strategies for improvement of the perception of the taste of frozen vegetable products.

The processing of vegetables into juices is considered as a good alternative to a fresh produce since it is regarded as "healthy" (28.6\%), "tasty" (15.5\%) and "high quality" (9.9\%) alternative to fresh produce. Frequently used pasteurization in the juice industry leads to undesirable changes in the organoleptic profile of products (Giner, 2013) and impair the retention of bioactive components (Rawson et al., 2011). Therefore, novel techniques like thermosonication (Anaya-Esparza et al., 2017) or high-pressure process (Liu, Zhang, Zhao, Wang \& Liao, 2016) could be alternatively utilized without altering the final quality of the juices. Preparation of vegetable juices in do- 
mestic circumstances in food processors and its immediate consumption after juicing are also alternatives for increased utilization of vegetables in a form of highly nutritious juices.

Safety is not, even for processed products, recognized among highly ranked reasons for vegetable consumption, although the concentration of pesticides might be reduced in a domestic environment and food industry by different methods (washing, frying, drying, cooking, peeling, freezing, fermenting, milling, juicing, etc.) depending on the various factors like the type of pesticide, its physicochemical characteristics, the contact time with the vegetable surface, the severity of applied processing technique etc. (Aguilera et al., 2014).

The findings of this study have to be seen in the light of the limited area in which the research was conducted because only the population of Vojvodina region was incorporated in the study. Therefore, further research could include a comparison of vegetable consumption in Vojvodina with other regions in Serbia and could include more different vegetable types.

\section{CONCLUSIONS}

The present study pinpointed the main viewpoints regarding vegetable consumption among residents of northern Serbia. In general, the vegetables are considered as tasty, easy to use and healthy for consumption. At the same time, the main drawbacks for vegetable consumption are safety issues, short shelf-life and high price. The results also showed that each type of vegetable, as well as each form of processed vegetable, should have a specifically tailored campaign, emphasizing its specific attribute. Having in mind that the consumption of vegetables is unsatisfactory, obtained results might be a valuable tool in improving current or creating new contemporary educational or mass media campaigns aiming to raise people's awareness of vegetables as an important and healthy ingredient in everyday diet. Also, present results might have a significant impact in creating different health protection programs which would promote vegetable consumption, and when applied, would consequently contribute to the improvement of public health.

\section{ACKNOWLEDGEMENTS}

This work was financially supported by the Ministry of Education, Science and Tech- nological Development (Serbia) under the Agreement on the Implementation and Financing of Research of the Institute of Food Technology (No.451-03-68/2020-14/200222), and Project "Development and utilization of novel and traditional technologies in production of competitive food products with added valued for national and global market CREATING WEALTH FROM THE WEALTH OF SERBIA" (III46001) financed by the Ministry of Education, Science and Technological Development (Serbia).

\section{REFERENCES}

Abou-Arab, A. A. K. (1999). Behavior of pesticides in tomatoes during commercial and home preparation. Food Chemistry, 65(4), 509-514. https://doi.org/10.1016/S0308-8146(98)00231-3

Aguilera, A., Valverde, A., Camacho, F., Boulaid, M., \& García-Fuentes, L. (2014). Household processing factors of acrinathrin, fipronil, kresoxim-methyl and pyridaben residues in green beans. Food Control, 35(1), 146-152. https://doi.org/10.1016/j.foodcont.2013.06.038

Allen, L., Williams, J., Townsend, N., Mikkelsen, B., Roberts, N., Foster, C., \& Wickramasinghe, K. (2017). Socioeconomic status and noncommunicable disease behavioural risk factors in low-income and lower-middle-income countries: a systematic review. The Lancet Global Health, 5(3), e277-e289. https://doi.org/10.1016/S2214-109X(17)30058-X

Anaya-Esparza, L. M., Velázquez-Estrada, R. M., Roig, A. X., García-Galindo, H. S., Sayago-Ayerdi, S. G., \& Montalvo-González, E. (2017). Thermosonication: An alternative processing for fruit and vegetable juices. Trends in Food Science \& Technology, 61, 26-37. https://doi.org/10.1016/j.tifs.2016.11.020

Arce, S., Gugole Ottaviano, F., \& Sosa, M. (2021). Sensory acceptability, consumption frequency, and factors associated with consumption of fruits and vegetables among low and medium income consumers in Argentina. Journal of Sensory Studies, 36(2), https://doi.org/10.1111/joss.12632

Beh, E. J. (2004). Simple correspondence analysis: a bibliographic review. International Statistical Review, 72(2), 257-284. https://doi.org/10.1111/j.17515823.2004.tb00236.x

Baselice, A., Colantuoni, F., Lass, D. A., Nardone, G., \& Stasi, A. (2017). Trends in EU consumers' attitude towards fresh-cut fruit and vegetables. Food Quality and Preference, 59, 87-96. https://doi.org/10.1016/j.foodqual.2017.01.008

Blanchard, C. M., Kupperman, J., Sparling, P. B., Nehl, E., Rhodes, R. E., Courneya, K. S., \& Baker, F. (2009). Do ethnicity and gender matter when using the theory of planned behavior to understand fruit and vegetable consumption? Appetite, 52(1), 15-20. https://doi.org/10.1016/j.appet.2008.07.001

Boeing, H., Bechthold, A., Bub, A., Ellinger, S., Haller, D., Kroke, A., Leschik-Bonnet, E., Müller, M. J., Oberritter, H., Schulze, M., Stehle, P., \& Watzl, B. 
(2012). Critical review: vegetables and fruit in the prevention of chronic diseases. European Journal of Nutrition, 51(6), 637-663. https://doi.org/10.1007/s00394-012-0380-y

Brown, C. (2003). Consumers' preferences for locally produced food: A study in southeast Missouri. American Journal of Alternative Agriculture, 213-224. https://doi.org/10.1079/AJAA200353

Cengiz, M. F., Certel, M., \& Göçmen, H. (2006). Residue contents of DDVP (Dichlorvos) and diazinon applied on cucumbers grown in greenhouses and their reduction by duration of a pre-harvest interval and post-harvest culinary applications. Food Chemistry, 98(1), 127-135.

https://doi.org/10.1016/j.foodchem.2005.05.064

Chapman, K., Goldsbury, D., Watson, W., Havill, M., Wellard, L., Hughes, C., Bauman, A., \& AllmanFarinelli, M. (2017). Exploring perceptions and beliefs about the cost of fruit and vegetables and whether they are barriers to higher consumption. Appetite, 113, 310-319. https://doi.org/10.1016/j.appet.2017.02.043

Coulibaly, O., Nouhoheflin, T., Aitchedji, C. C., Cherry, A. J., \& Adegbola, P. (2011). Consumers' perceptions and willingness to pay for organically grown vegetables. International Journal of Vegetable Science, 17(4), 349-362. https://doi.org/10.1080/19315260.2011.563276

Emanuel, A. S., McCully, S. N., Gallagher, K. M., \& Updegraff, J. A. (2012). Theory of planned behavior explains gender difference in fruit and vegetable consumption. Appetite, 59(3), 693-697. https://doi.org/10.1016/j.appet.2012.08.007

Featherstone, S. (Ed.). (2015). A complete course in canning and related processes: Volume 3 Processing procedures for canned food products. Woodhead Publishing. https://doi.org/10.1016/B978-0-85709679-1.00001-5

Giner, M. J., Hizarci, Õ., Martí, N., Saura, D., \& Valero, M. (2013). Novel approaches to reduce brown pigment formation and color changes in thermal pasteurized tomato juice. European Food Research and Technology, 236(3), 507-515. https://doi.org/10.1007/s00217-012-1900-y

Greenacre, M. (2017). Correspondence analysis in practice ( $3^{\text {rd }}$ ed.). Chapman and Hall/CRC.

Guerrero, J. F. J., Abad, J. C. G., García, R. H., \& Jiménez, J. A. M. (2012). Estimating consumer preferences for extrinsic and intrinsic attributes of vegetables. A study of German consumers. Spanish Journal of Agricultural Research, 10(3), 539-551. http://dx.doi.org/10.5424/sjar/2012103-342-11

Hoffman, D. L., \& Franke, G. R. (1986). Correspondence analysis: graphical representation of categorical data in marketing research. Journal of Marketing Research, 23(3), 213-227. https://doi.org/10.1177/002224378602300302

Hough, G., \& Ferraris, D. (2010). Free listing: A method to gain initial insight of a food category. Food Quality and Preference, 21(3), 295-301. https://doi.org/10.1016/j.foodqual.2009.04.001

Institute of Public Health of Serbia (2019). Health statistical yearbook of Republic of Serbia, year 2018 (p. 527). Belgrade: Institute of Public Health of Serbia "Dr Milan Jovanović Batut" http://www.batut.org.rs/download/publikacije/pub2 018.pdf?fbclid=IwAR0EF0AdMIu.
Ion, R. A. (2015). Fruits and vegetables market in Romania: Better understand consumers' preferences. In the $6^{\text {th }}$ Edition of the International Symposium on Agrarian Economy and Rural DevelopmentRealities and Perspectives for Romania (pp. 426433). Bucharest, Romania. http://hdl.handle.net/10419/163338

Ivy, J. (2001). Higher education institution image: a correspondence analysis approach. International Journal of Educational Management. https://doi.org/10.1108/09513540110401484.

Jha, P. K., Xanthakis, E., Chevallier, S., Jury, V., \& LeBail, A. (2019). Assessment of freeze damage in fruits and vegetables. Food Research International, 121, 479-496. https://doi.org/10.1016/j.foodres.2018.12.002

Lebart, L. (1984). Correspondence analysis of graph structure. Bulletin Technique du CESIA, Paris, 2, 5-19.

Li, L., Pegg, R. B., Eitenmiller, R. R., Chun, J. Y., \& Kerrihard, A. L. (2017). Selected nutrient analyses of fresh, fresh-stored, and frozen fruits and vegetables. Journal of Food Composition and Analysis, 59, 8-17. https://doi.org/10.1016/j.jfca.2017.02.002

Liu, F., Zhang, X., Zhao, L., Wang, Y., \& Liao, X. (2016). Potential of high-pressure processing and hightemperature/short-time thermal processing on microbial, physicochemical and sensory assurance of clear cucumber juice. Innovative Food Science \& Emerging Technologies, 34, 51-58. https://doi.org/10.1016/j.ifset.2015.12.030

Menozzi, D., Sogari, G., \& Mora, C. (2015). Explaining vegetable consumption among young adults: An application of the theory of planned behaviour. Nutrients, 7(9), 7633-7650. https://doi.org/10.3390/nu7095357

Mihajlović, Š., Vukelić, N., Novković, N., \& Mutavdžić, B. (2019). Vegetable prices in Serbia-tendencies and forecasting. Ekonomika poljoprivrede, 66(2), 485-498. https://doi.org/10.5937/ekoPolj1902485S.

Nguyen, B., Bauman, A., Gale, J., Banks, E., Kritharides, L., \& Ding, D. (2016). Fruit and vegetable consumption and all-cause mortality: evidence from a large Australian cohort study. International Journal of Behavioral Nutrition and Physical Activity, 13(1), 1-10. https://doi.org/10.1186/s12966-016-0334-5

Pucarević, M. (2008). Pesticide residues in fruits and vegetables. Zbornik radova Instituta za ratarstvo $i$ povrtarstvo, 45(1), 195-203.

Rawson, A., Patras, A., Tiwari, B. K., Noci, F., Koutchma, T., \& Brunton, N. (2011). Effect of thermal and non-thermal processing technologies on the bioactive content of exotic fruits and their products: Review of recent advances. Food Research International, 44(7), 1875-1887. https://doi.org/10.1016/j.foodres.2011.02.053

Renard, C. M., Ginies, C., Gouble, B., Bureau, S., \& Causse, M. (2013). Home conservation strategies for tomato (Solanum lycopersicum): Storage temperature vs. duration-Is there a compromise for better aroma preservation? Food Chemistry, 139(14), 825-836. https://doi.org/10.1016/j.foodchem.2013.01.038

Rickman, J.C., Barrett, D.M., \& Bruhn, C.M. (2007). Nutritional comparison of fresh, frozen and canned 
fruits and vegetables. Part 1. Vitamins $\mathrm{C}$ and $\mathrm{B}$ and phenolic compounds. Journal of the Science of Food and Agriculture, 87, 930-944.

https://doi.org/10.1002/jsfa.2825

Rodić-Trmčić, B., Ivanović, M., \& Ilić, V. (2015). The quality of nourishment in the population across the regions of the Republic of Serbia from 2011 to 2013. PONS-medicinski časopis, 12(2), 58-63. https://doi.org/10.5937/pomc12-9098

Viana, F. M., Deliza, R., Monteiro, M. L. G., Martins, I. B., de Oliveira, D. C., \& Conte-Junior, C. A. (2021). Applying free word association to understand the perception of fish as a meal by Brazilians with different consumption frequencies. Journal of Sensory Studies, 36(2), e12628

https://doi.org/10.1111/joss.12628
Wood, K., Carragher, J., \& Davis, R. (2017). Australian consumers' insights into potatoes-Nutritional knowledge, perceptions and beliefs. Appetite, 114, 169-174. https://doi.org/10.1016/j.appet.2017.03.038

World Health Organization (2003). Diet, Nutrition and the Prevention of Chronic Diseases. WHO Technical Report Series 916.Geneva: WHO.

http://apps.who.int/iris/bitstream/handle/10665/426 65/WHO_TRS_916.pdf; jsessionid=8551E0A498E D22F19423BB8B891AEA24? sequence $=1$

Zeinstra, G. G., Koelen, M. A., Kok, F. J., \& De Graaf, C. (2007). Cognitive development and children's perceptions of fruit and vegetables; a qualitative study. International Journal of Behavioral Nutrition and Physical Activity, 4(1), 1-11. https://doi.org/10.1186/1479-5868-4-30 


\section{ISPITIVANJE STAVOVA POTROŠAČA I FAKTORA KOJI UTIČU NA KONZUMACIJU POVRĆA}

Dragana N. Ubiparip Samek ${ }^{* 1}$, Aleksandra R. Bajić ${ }^{1}$, Lato L. Pezo², Renata M. Kovač ${ }^{2}$, Jasna S. Mastilović ${ }^{1}$, Tihomir S. Zoranović ${ }^{3}$, Branislav I. Vlahović ${ }^{3}$

${ }^{1}$ Univerzitet u Novom Sadu, Naučni institut za prehrambene tehnologije, 21000 Novi Sad, Bul. cara Lazara 1, Srbija

${ }^{2}$ Univerzitet u Beogradu, Institut za opštu i fizičku hemiju, 11000 Beograd, Studentski trg 12/V, Srbija

${ }^{3}$ Univerzitet u Novom Sadu, Poljoprivredni fakultet, Departman za ekonomiku poljoprivrede i sociologiju sela, 21000 Novi Sad, Trg D. Obradovića 8, Srbija

Sažetak: U cilju povećanja potrošnje povrća i pružanja korisnih infromacija potrošačima, analizirane su njihovi stavovi kao i razlozi koji utiču na konzumaciju ovih namirnica. Da bi se ostvario uvid u opšte karakteristike potrošnje povrća korišćen je online upitnik, a istraživanje je sprovedeno na uzorku od 711 slučajno izabranih ispitanika. Za utvrđivanje stavova potrošača o svežem i prerađenom povrću upotrebljena je analiza korespondencije. Rezultati su pokazali da potrošači povrće smatraju ukusnim, lakim za upotrebu i zdravim, dok se glavni nedostaci odnose na bezbednost, kratak rok trajanja i visoku cenu ovih namirnica. Kako bi se povećala potrošnja svežeg i prerađenog povrća, potrebno je da postoje posebno dizajnirane promotivne kampanje koje bi isticale njihove prednosti i doprinos zdravstvenom stanju pri svakodnenvoj konzumaciji. Rezultati dobijeni ovom studijom pružaju uvid u trenutno stanje ponašanja potrošača u Srbiji i mogli bi biti korisni za kreiranje specifičnih promotivnih programa i strategija komunikacije, kako bi uticali na povećanje znanja potrošača o značaju povrća u ishrani. Kampanje treba da budu usmerene ka podizanju svesti potrošača o dobrobiti svakodnevne konzumacije povrća čime bi se poboljšalo opšte zdravstveno stanje populacije i ujedno smanjili troškovi lečenja sve više prisutnih masovnih hroničnih bolesti izazvanih neadekvatnom ishranom.

Ključne reči: ponašanje potrošača, sveže povrće, prerađeno povrće, analiza korespondencije

Received: 04 June 2021/Received in revised form: 29 June 2021/Accepted: 30 June 2021

Available online: June 2021

This is an open-access article under the CC BY license (http://creativecommons.org/licenses/by/3.0). 